\author{
Andrea Bernini \\ University of Heidelberg, Germany
}

\title{
COMPARING ENGLISH IN THE CONTEMPORARY WORLD AND LATIN IN THE ROMAN EMPIRE: IS LINGUISTIC IMPERIALISM A NEW PHENOMENON?
}

\begin{abstract}
Summary. Some scholars support the existence of a close similarity between the role played by Latin in the Roman Empire and by English in the contemporary world as supra-local languages, by resorting to the assumption of a close similarity between the Roman Empire and today's globalized world. However, an overview on these two historical phenomena shows substantial differences. First of all, Latin was the supra-local language par excellence only in the Western part of the empire, because in the Eastern part this role was mostly played by Greek. In addition, during the Roman Empire Latin was the language of the administration, but on the whole it did not have a notable clout, since the actors that had traditionally played a key-role in spreading languages in Modern Europe were absent: the concept of national language was unknown, there was no compulsory education, and nothing comparable to mass-media existed. By focusing on the contemporary globalized society, one can observe that language is crucial in legitimizing the institutions, in supporting specific economic powers and the cultures related to such powers. In particular, the current linguistic imperialism of English is strictly bound to those economic powers that interlock with (and take advantage of) political, military, educational structures and mass-media (as significantly witnessed by the processes of McDonaldization and Coca-Colonization). The present comparison between past and present situations is not limited to these situations as such, but is aimed at better highlighting the respective differences: in this case, the recourse to the past is useful to see the contemporary issues concerning multilingualism under a different viewpoint.
\end{abstract}

Keywords: Ancient Latin, English, linguistic imperialism, Roman Empire, globalization, language policy.

\section{Introduction*}

Roman Empire has traditionally been admired in the past as well as in the present not just for its culture, but also for its historical relevance. Nowadays, Ancient Latin is not infrequently compared by scholars to English that has spread

\footnotetext{
* The text is a revised version of the speech: 'Comparing Latin in Ancient World and Today's English: is Linguistic Imperialism a New Phenomenon?', $3^{\text {rd }}$ International Scientific Conference Darnioji daugiakalbystè: kalba, kultūra, visuomenè/Sustainable Multilingualism: Language, Culture and Society, Vytauto Didžiojo universitetas, Kaunas, 29-30 May 2015.
} 
worldwide as the global language par excellence thanks to the Anglo-Saxon hegemony (through the British Empire in the past, and the American influence in the current times). These comparisons are sometimes en passant, sometimes more complex, but they share the tendency of considering both Latin in the Roman Empire and today's English as the actors of two linguistic imperialisms.

Starting from the positions of scholars, divided between those who support a strict analogy between the two cases and those who refuse it, the paper focuses on the main aspects of the relation language-power-identity in the Roman Empire and the features of the linguistic imperialism of English within the context of globalization, in order to prove whether linguistic imperialism can be referred to the ancient world, or rather such a phenomenon should be considered only as a product of the contemporary world. This comparison is not easy, since the knowledge of the ancient world is undermined by the scarcity of sources (which are obviously all written $)^{1}$, but it is justified by the more and more frequent recourse to terminology referred to the contemporary world also in the studies focusing on the ancient world ${ }^{2}$. In addition, the comparison between past and present is useful for contemporary sociolinguistic issues, providing insights on the topic of multilingualism and the power ratio between languages.

\section{Similarities between Ancient Latin and today's English}

The equivalence between Ancient Latin and today's English has been proposed by studies focusing on contemporary times as well as by studies related to the ancient world. Among the first ones, the work of Crystal (1997) is particularly interesting. While dealing with the topic of English as a global language, he observes that the condition of global language is not necessarily

\footnotetext{
${ }^{1}$ Ancient sources present three main problems in the reconstruction of the past: 1 . the very low number of literate people; 2 . the numerous formulaic expressions contained in the texts; 3. the impossibility (in the most cases) to identify the speakers (Torallas Tovar 2010, pp. 17$18,28,42-43)$.

2 See, for instance, the scholars quoted in the article who use the expression 'linguistic imperialism' in relation to the ancient world, and Mullen, 2013, p. 298, who refers to modern concepts like 'symbolic power' and 'linguistic capital'.
} 
due to the hugest number of speakers, but rather to their identity: from this perspective, he refers to Latin in the Roman Empire, stating that its role as an international language derived from being a powerful language. Power is exactly the main feature of a global or international language, since "[t]here is the closest of links between language dominance and cultural power", and "[a] language becomes an international language for one chief reason: the political power of its people - especially the military power" (two powers that are strictly bond to the economic one). In general, this fact is not explicitly admitted by the forces that support international languages: on the contrary, such languages are usually claimed to have the best aesthetic qualities, to better fit particular (religious and non-religious) needs, to be naturally easier. However, an inspection of the past and present international languages (such as Hebrew, Greek, Arabic, French, Spanish, Russian) demonstrates that typologically different idioms can become international languages (ibid., pp. 5-7).

Latin has also been labeled as a lingua franca. In his overview, Barotchi (2001, p. 504) mentions modern lingua francas (such as English) as well as the ancient ones, among which he lists Latin, considered as a lingua franca both in the Roman Empire and in the Christian world (as the language of the Catholic Church). A comparison based on a historical perspective is carried out by Mufwene (2010, p. 50), who asserts that today's English is evolving towards many World Englishes, rather than being preserved almost unchanged: he compares this situation to the one of Ancient Latin, which was a global language during the Roman Empire, but after its fall it has evolved so as to generate various Romance idioms.

Regarding the studies focusing on Antiquity ${ }^{3}$, Farrell (2001, pp. 2-4) refers to the perception of Latin as a civilizing force: according to this viewpoint, the Aeneid is a foundational text, representing the overwhelming power of Latin culture. He writes openly of a Latin linguistic imperialism, by stating that "[t]he effects of Roman linguistic imperialism were real" with reference to various sources glorifying Latin culture, among which a couplet of Martial (Spectacula 3.11-12) can be quoted: Vox diversa sonat populorum, tum tamen una est, / Cum verus patriae

\footnotetext{
3 Positions entailing a very wide interpretation of linguistic imperialism are not taken into consideration, such as the one of Rivet and Smith (1979, p. 22): "[0]ne general impression which emerges is that the Roman invaders were not linguistic imperialists. When a place had a name, the Roman Army, administration and settlers adopted it without question, merely latinising its form and fitting it into a declension".
} 
diceris esse pater ${ }^{4}$. More recently, while dealing with the role of Latin in relation to the other languages spoken within the borders of the Roman Empire, Mullen (2011, pp. 535-536) also supports a close parallelism between Latin and English:

\begin{abstract}
"[i]n the absence of a systematic language policy [...] or widespread, centrally organized education, the spread of Latin in the West can be compared to that of English today. Latin was not forced upon the inhabitants of the societies in the West, but was rather chosen as having a high cultural, political, legal, social and economic value for its speakers" ${ }^{\prime}$.
\end{abstract}

\title{
English language (and power) in today's world
}

\section{Globalization and languages in the contemporary world}

Within the context of globalization that tends towards the unipolar world, English (and world Englishes) imposes itself on a global scale at various levels, as the leading language(s). Thus globalization is not only closely related to the political and economic aspects, but it deeply affects the linguistic aspects as well ${ }^{6}$.

The current condition of English worldwide (which can be positively or negatively considered, as done respectively by 'localists' and 'globalists', see James, 2009, p. 81) can be described as a threefold condition, given the existence of three types of globalising Englishes:

1. Global English: "[t]he kind of globalising/globalised form of English that is often primarily envisaged in - predominantly negatively loaded -

\footnotetext{
4 "The speech of the peoples sounds different and yet, when you are hailed as the true father of the fatherland, they all speak as one" (transl. by Coleman, 2006, p. 37).

${ }^{5}$ She states elsewhere (Mullen, 2013, p. 298) Latin to have been an extremely successful language (in terms of 'symbolic power' and 'linguistic capital'), the knowledge of which brought concrete benefits to the speakers, and she reasserts the analogy with English in the fact that Latin had also widely spread without a systematic language policy. This view echoes the assumption that Romans would have not imposed Latin language to the conquered people (see, e.g., Moggi, 1998).

6 Arcangeli (2005, pp. 9-30) deals with these effects on the language, highlights the economic-political and imperialist aspects of globalization, and asserts the present situation to have been prefigured by specific artists and intellectuals of the 20th century, such as Marinetti (the concept of 'eternal present' closely resembles the Internet), Warhol (the 'seriality' of his works is similar to the consumerist and advertising aspects of the current economy), and Dali (his painting The Persistence of Memory prefigures Bauman's concept of 'liquid modernity').
} 
discussions of the influence of the language worldwide is indeed the kind of dominant English as a threat to glossodiversity registered by the linguistics 'globalists' referred to above" (ibid., p. 84);

2. World Englishes: "[t]he term 'World Englishes' is conventionally employed in the sociolinguistic literature for those Englishes which have developed via British (and American) colonialism of the past centuries, often excluding the Englishes of the white settler colonies such as Australia, Canada, New Zealand (and South Africa)." (ibid., p. 85);

3. Lingua Franca English: "[i]t has been noted repeatedly in recent accounts of English worldwide that the number of users who do not have the language as their 'native language' or 'L1', i.e. the 'non-native speakers', now far outnumber the conventional 'native speakers' of the UK, the US, Australia, etc. and that the percentage of interchanges in English between such non-natives far outnumber those between natives - or between nonnatives and natives" (ibid., pp. 85-86).

\section{Main features of today's linguistic imperialism of English}

The bond between language and power is not a new phenomenon originating from globalization, but has been present for centuries both inside the states ${ }^{7}$ and outside them: the power of English, French, Spanish and Portuguese outside Europe is a consequence of the respective empires of the past (Phillipson, 2012, pp. 205-206) ${ }^{8}$. In particular, the English neo-imperial language policy is due to three main phenomena (Phillipson, 2012, p. 222): the role played by English in the British Empire; the strength of the American economy in the $20^{\text {th }}$ century; and the global power structures put in place since $1945^{\circ}$. These factors have led to

\footnotetext{
7 "Within Europe, the expansion of dominant 'national' languages was generally at the expense of other languages, in processes of country-internal colonization" (Phillipson, 2012, p. 204). For some remarks on the language policies of the nation-states see, e.g., Bernini (2014, pp. 168-170).

8 See also Mufwene (2010, p. 50), who deals with the global spread of English due to colonization and globalization.

${ }^{9}$ Schneider (2011, p. 336-343) asserts the persistence of English (or of the related pidgins and creoles) in the former colonies of the UK and USA to be due to the fact that English is a neutral language compared to local ethnic groups, and that it offers many possibilities within the global market (in the former colonies as well as in other states). The pervasive force of English has implications for the continuum between globalization and localization: in this context English is perceived both as the global language, and as a local language in the form of various New Englishes, which are in many cases learned as mother tongues.
} 
linguistic imperialism that is characterized by the following features (Phillipson and Skutnabb-Kangas, $2013^{2}$, pp. 499-500 ${ }^{10}$ :

1. it interlocks with a structure of imperialism in culture, education, the media, communication, the economy, politics and military activities;

2. it is about exploitation, injustice, inequality and hierarchy that privileges those who master the dominant language;

3. it is structural: resources and infrastructures are mostly accorded to the dominant language;

4. it is ideological, implying the glorification of the dominant language and the stigmatization of the others;

5. the dominance is hegemonic;

6. it entails unequal rights for different speakers/signers;

7. language learning and use is often subtractive;

8. it is a form of linguicism;

9. it is invariably contested and resisted.

From these remarks it emerges clearly that English is not much connected with the idea of ethnic identification (which is typical of the nation-state model ${ }^{11}$ ), but linguistic imperialism, through a sort of 'cultural identity' ${ }^{12}$ with the Anglo-Saxon world, favors the political-economical plans of that world: as a consequence the language is perceived as a marker of status, being the economic marker of the most important economy, and takes the form of language policies profitable to English.

\section{Latin language (and power) in the Roman Empire}

\section{Roman imperialism}

Although the Roman state is labeled as an 'empire', it differs quite much from the empires that existed in more recent times. Such a difference is mirrored in various

\footnotetext{
${ }^{10}$ See also the interpretation of English as lingua frankensteinia and lingua tyrannosaura proposed by Phillipson (2008).

${ }^{11}$ See, e. g., Dell'Aquila and Iannàccaro (2004, pp. 29-37) and Bernini (2014, pp. 168-170).

12 For the interpretation of linguistic imperialism as cultural imperialism, see Pupavac (2012, pp. 123-128). In her book, the position of Holborow should be highlighted, who asserts that supporting national languages against linguistic imperialism does not "necessarily lead in emancipatory directions" (quoted ibid., p. 127).
} 
definitions given by the scholars: Richardson (2011, pp. 192-193) theorizes the existence of a series of imperialisms rather than of one Roman imperialism, because Rome's expansion evolved from a 'power-by-conquest' model to one of 'power-as-possession'; Edwell (2012, p. 40) uses the term 'hegemony' instead of 'imperialism', the last one being closely bound to recent historical phenomena; according to Erskine and Mitchell (2012, p. 3427-3428), Roman imperialism was not territorial, and Rome was represented as a benefactor, as evident in the expansion in Greece, which is presented as a protection given to Greek people, threatened by Illyrians.

However, the Roman Empire remained an institution of power, even though less radical than the current traditional nation-state model. For instance, by focusing on Augustus' times (during which the Roman Empire strengthened), one notices the presence of an imperial ideology in the fields of art, archaeology and literature (but without any programmatic or philosophical expression). Rome sought a justification to its expansionism: "[t]he laws were thus presented as enforcing a disciplinary régime once enforced by traditional values, an encroachment on individual liberty justified in imperial terms. In Augustan culture, the Empire was everywhere represented as the telos of the Roman state, its raison

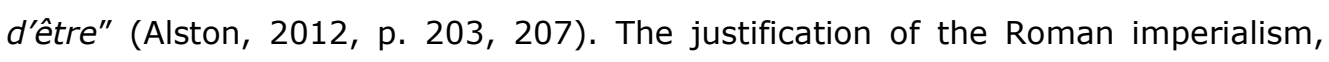
according to which Rome brings peace and justice, was emblematically rendered by the Augustan poet Virgil (Aeneis 6.851-853); in his masterpiece, the soul of Anchises predicts to his son Aeneas the future role of Roman power: tu regere imperio populos, Romane, memento / (hae tibi erunt artes), pacique imponere morem, / parcere subiectis et debellare superbos ${ }^{13}$.

Although the imperialist propaganda and rhetoric tried to present Roman expansion as an advantage for everyone, the abuse of power was concealed by vanquished people: their point of view clearly emerges in various works that criticize Roman imperialism. As reported by Caesar (De Bello Gallico 7.77), the Gaulish warrior Critognatus spurred his soldiers to withstand the Roman assaults during the battle in Alesia, by blaming the insatiable thirst for wealth of the invaders: Romani vero quid petunt aliud aut quid volunt, nisi invidia adducti, quos

\footnotetext{
13 "[Y]ou, Roman, be sure to rule the world (be these your arts), to crown peace with justice, to spare the vanquished and to crush the proud" (transl. by Fairclough Rushton, 19992, p. 593).
} 
fama nobiles potentesque bello cognoverunt, horum in agris civitatibusque considere atque his aeternam iniungere servitutem (14 $^{14}$

Another important evidence, referable to a very similar situation (i.e., the war between the Roman army and Caledonians), is preserved by Tacitus (Agricola, 30.5-6). The Caledonian chieftain Calgacus gave a speech through which he strongly condemned not just the lust for power of the enemies, but also the ideal of the pax romana that was the cornerstone for justifying Roman expansionism:

raptores orbis, postquam cuncta vastantibus defuere terrae, mare scrutantur: si locuples hostis est, avari, si pauper, ambitiosi, quos non Oriens, non Occidens satiaverit: soli omnium opes atque inopiam pari adfectu concupiscunt. auferre trucidare rapere falsis nominibus imperium, atque ubi solitudinem faciunt, pacem appellant ${ }^{15}$.

Later, when Christianity spread into the empire, the critique to Roman power became even harder and charged itself of further meanings, by concerning the essence itself of temporal power, as evident in the words of Saint Augustine (De civitate Dei 4.4):

[r]emota itaque iustitia quid sunt regna nisi magna latrocinia? [...] Eleganter enim et veraciter Alexandro illi Magno quidam comprehensus pirata respondit. Nam cum idem rex hominem interrogaret, quid ei videretur, ut mare haberet infestum, ille libera contumacia: Quod tibi, inquit, ut orbem terrarum; sed quia <id> ego exiguo navigio facio, latro vocor; quia tu magna classe, imperator $^{16}$.

\footnotetext{
14 "But the Romans - what else do they seek or desire than to follow where envy leads, to settle in the lands and states of men whose noble report and martial strength they have learnt, and to bind upon them a perpetual slavery?" (transl. by Edwards, 1917, p. 495).

15 "Robbers of the world, now that earth fails their all - devastating hands, they probe even the sea: if their enemy have wealth, they have greed; if he be poor, they are ambitious; East nor West has glutted them; alone of mankind they covet with the same passion want as much as wealth. To plunder, butcher, steal, these things they misname empire: they make a desolation and they call it peace." (transl. by Hutton and Peterson, 1970, p. 81).

16 "And so if justice is left out, what are kingdoms except great robber bands? [...] For it was an elegant and true reply that was made to Alexander the Great by a certain pirate whom he had captured. When the king asked him what he was thinking of, that he should molest the sea, he said with defiant independence: "The same as you when you molest the world! Since
} 


\section{A globalized empire?}

The label 'globalization', widely used to indicate particular trends of current society, has also been referred to the Roman Empire by some scholars. The papers collected by Pitts and Versluys (2014) resort to the term 'globalization' in offering historical and archaeological insights about the Roman world; 'globalization' is used also by Witcher (2000) in addressing identity in Roman Italy (although he is aware of the differences between the contemporary and the ancient worlds) ${ }^{17}$, by stating that (ibid., p. 223) "[b]oth the modern and ancient worlds involve overlapping scales of identity - global, national, regional, and local. The key is to locate these multiple identities in relation one another". Sommer (2013) goes even beyond the concept of globalization and resorts to the word 'glocalization' by analysing the persistence of different cultural identities in the Roman Empire, stating that "[g]lobalisation and localisation went hand in hand in the Roman world as much as today" (ibid., p. 349).

However, other scholars do not adopt this terminology, by resorting to the great difference between the two historical contexts. Naerebout (2006-2007, p. 167) clearly defines the Roman world as "a quintessentially unglobalised world", and Hitchner (2008) argues that the presence of "instances of interconnectedness and integration in historical societies" should not be interpreted as a globalization, because "the presence of some symptoms of globalization does not [make] a globalization". Alonso-Núñez (2004, pp. 5-7) notices that in the ancient world the goal of imperialism is the control upon peoples and states, with no economic planning as in the contemporary world. Moreover, the concept of 'imperialism' is political, while 'globalization' is economic: therefore, the former has a historical continuity; the latter is a totally new phenomenon. According to these remarks, concepts strictly linked to modern phenomena should not be used to indicate ancient phenomena.

I do this with a little ship I am called a pirate. You do it with a great fleet and are called an emperor"." (transl. by Green, 1963, p. 17).

17 "I do not intend to claim that theories of globalisation can be applied wholesale to the past - indeed, as a process, globalisation is itself intimately associated with the condition of modernity, i.e. imperialism, (post-/neo-)colonialism, capitalism, industrialisation, rationalisation and telecommunications, etc. [...]. Rather, I wish simply to suggest that globalisation offers both a vocabulary and a series of models with which to explore identities in Roman Italy" (Witcher, 2000, p. 214). 


\section{Was language an identity marker?}

On the whole, in the ancient times language was certainly an identity marker, but its importance varied depending on the context, as seen in those cases in which the maintenance of one's own non-Latin identity clearly emerges: in some inscriptions from Italy the Latinized names of Etruscan people preserve an Etruscan morphology (Adams, 2003, p. 182); some Punic coins preserve the usual Latin legend for the name of the emperor, but the toponym is expressed in Punic language (ibid. pp. 208-209); in various Graeco-Latin inscriptions concerning Greeks at Rome, Greek stresses the provenance of people (ibid., pp. 348-349, 363-369) ${ }^{18}$. In addition, language can be a 'professional' marker in the case of particular professions, such as doctors, teachers and flutists (ibid., pp. 356-360), and above all in relation to the 'political' aspects. In fact, Latin was the language of law, of the army and of the governors, being in particular a prerequisite for the acquisition of Roman citizenship (Rochette, 2011, pp. 552-557) ${ }^{19}$ : therefore, the use of Latin was not an imposition stricto sensu, but a concession that brought legal advantages (Oniga, 1998, pp. 573-575). The evidence that has come to us suggests that Latin, beside some identitarian features, was more perceived as a language of prestige (see, e.g., Rochette, 2011).

\section{Did the Roman Empire carry out a language policy?}

When dealing with the founding characteristics of a state, nowadays it is natural to think of language policy, especially when the language of the conquerors far exceeds the area in which it was originally spoken, spreading over most of the conquered territories (like in the case of the Roman Empire).

\footnotetext{
${ }^{18}$ In the Greek-speaking world language was very important, because Greek people paid scarce attention to the languages of the others (the $\beta$ ápßapoı), but a great one for their own language. They seemed to conceive the world as divided in two categories: the homoglossoi ('of the same tongue', i.e. the Greeks) and the heteroglossoi ('of a different language', i.e. the 'barbaroi'); as a consequence, the Greeks seldom learned the other languages, unlike the 'barbaroi', who often learned the idioms of the others (Moggi, 1998). In the Greek world priority was given to the linguistic aspect, rather than to the biological one, since the language and the ethnicity had been traditionally considered equivalent: those who were not Greek, after learning the language became Greek (Anson, 2009, pp. 11, 15-16, 25-26).

${ }_{19}$ On the contrary, in the Eastern part (like in Egypt) Latin was a prestige language sometimes used in inscriptions and documents (Rochette, 2011, pp. 556-557). Concerning the case of Egypt (of which we have numerous evidences) ethnic identity was based sometimes on cultural and religious aspects, but there are no evidences that language was the yardstick (Vandorpe, 2012, pp. 268-271).
} 
Indeed, the bond between the Roman Empire and Latin language seemed to have been very close according to a couple of passages from two authoritative intellectuals. In a passage concerning the future power of Rome, towards the end of Virgil's Aeneid (12.834-837) the spread of Latin language all over the world is foreseen through these words: sermonem Ausonii patrium moresque tenebunt, / utque est nomen erit; commixti corpore tantum / subsident Teucri. morem ritusque sacrorum / faciamque omnis uno ore Latinos ${ }^{20}$. The close correlation between political power and linguistic power was not limited to the golden age of Rome, but it is likely to have been a constant feature of the Roman Empire, since it was also present in the Late Empire, when Saint Augustine acknowledged the expansion of Rome together with the parallel expansion of its own language ( $D e$ civitate Dei 19.7): [a]t enim opera data est, ut imperiosa civitas non solum iugum, verum etiam linguam suam domitis gentibus per pacem societatis imponeret, per quam non deesset, immo abundaret etiam interpretum copia ${ }^{21}$.

Different viewpoints are shared by classicists in relation to the existence of a Roman language policy, or of a close bond politics-language. There are who, like Rochette (1995, p. 13), speak of an imperialism characterizing the Graeco-Roman world, because the linguistic panorama of the classical world seemed to be dominated by two languages, Greek and Latin, to which a huge number of 'barbaric' idioms were placed side by side, that in a certain sense appeared to form

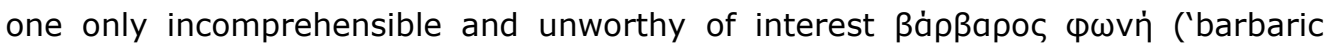
language'). As a consequence, Greek- and Latin-speakers did not need to learn other languages, but others needed to know theirs.

For Dubuisson (1982, p. 209), the Roman state did not show a particular attitude in regard to foreign languages, and the indifference in respect of languages other than Greek and Latin prevailed. He concisely writes that "[r]ien ne permet de penser qu'il y ait eu, à l'un ou l'autre moment, un «impérialisme linguistique» romain. C'est-a-dire des efforts pour imposer l'usage du latin aux pays conquis": according to him, "[i]l s'agit en somme bien plus de protectionnisme que d'imperialisme". He asserts that the boost to Romanization

\footnotetext{
20 "Ausonia's sons shall keep their fathers' speech and ways, and as it is now, so shall their name be: the Teucrians shall but sink down, merged in the mass, I will give them their sacred laws and rites and make them all Latins of one tongue" (transl. by Fairclogh Rushton, $2001^{2}$, p. 359).

21 "But the imperial city has taken pains to impose on conquered peoples, as a bond of peace, not only her yoke but her language, so that there has been far from a lack, but rather a superfluity, of interpreters." (transl. by Greene, 1960, p. 149).
} 
was given by the vanquished peoples themselves rather than imposed by the Romans: if at most one wants to support the idea of a Roman language policy, this should be interpreted as a defence from the linguistic imperialism of the other great language of the ancient world, i.e. the Greek language.

As already stated by Adams (2003, pp. 757-759), Mullen (2013, p. 298) also refuses the idea of a real language policy in Rome, perceiving the expansion of Latin as a spontaneous phenomenon (Mullen, 2011, p. 535-536, quoted supra) ${ }^{22}$ : the absence of a language policy is evident, especially in comparison with the contemporary world ${ }^{23}$, in the fact that in the Roman Empire the education system was neither controlled nor planned by the state, and the teachers were paid privately (for an overview see Christes, 2001) ${ }^{24}$. As stated by Eck (2004, pp. 5$6)^{25}$ and reasserted by Rochette (2011, p. 557), Romans had a twofold approach to languages, based on (1) (re)affirming their superiority through Latin, and on (2) a practical approach founded on the tolerance towards the other idioms (parallel to the preeminence of Latin). However, they (Rochette, 2011, p. 535) support the existence of a language policy carried out by the Romans that succeeded in spreading Latin in the Western part of the Empire ${ }^{26}$, since the Eastern part continued to be mostly Greek-speaking ${ }^{27}$ : a sociolinguistic panorama that can be broadly defined as a 'bilateral monolingualism'.

\footnotetext{
${ }^{22}$ In partial contrast to the alleged spontaneousness of the spread of Latin is Oniga (1998, p. 575), who writes that, even though no law had never obliged people to speak Latin, it undoubtedly provided tangible advantages, thus leading vanquished people to learn it spontaneously.

${ }^{23}$ For an overview on the role played by school in the nation-states, see Dell'Aquila and Iannàccaro (2004, pp. 30-32).

${ }^{24}$ The complete study course consisted of three levels: the pupil was educated by the ludi magister from 7 to 11 years old, then by the grammaticus from $11 / 12$ to $16 / 17$, and the education could continue under the rhetor (Christes, 2001).

${ }^{25}$ As Eck $(2004$, p. 5) notices, languages have always been used (to different extents) by the power: "[d]aß ein Weltreich seine eigene Sprache als wichtiges Herrschaftsinstrument, aber auch als Mittel zur Selbstdarstellung benützt, ist eine zeitlose Erscheinung. Auch Rom wußte das und nutzte die Sprache".

${ }^{26}$ Training the sons of local aristocracies in liberal arts was a way to integrate the vanquished people into the Roman Empire: as witnessed for the western part of the empire, the prestige and the status of Latin led the noblemen to encourage their children to study Latin (Adams, 2003, pp. 691-692).

27 The legal field represents an exception, since Latin occupied a stronger position than Greek, as demonstrated by the fact that the original copies of Greek documents had to be written in Latin (Rochette, 2011, p. 553).
} 


\section{Main differences between today's English and Ancient Latin}

The current globalized, English-speaking world and the Roman Empire share some similarities in that both English and Latin have been linked (to a different extent) to structures of power, but the previous remarks show that the two contexts are substantially very different. The first major difference is that, whereas no other language can nowadays be at the level of English, in the Roman Empire Latin was the supra-local language only for the western part, because in the eastern part this role was mostly played by Greek; in addition, the extensive use of interpreters (see, e.g., Saint Augustine, De civitate Dei 19.7, quoted supra) suggests that the spread of Latin and the presence of interpreters were parallel phenomena.

Beside these affinities, there are substantial differences involving the following aspects:

1. historical: the spread of Latin in the colonized territories was not as rooted as that of English (only a portion of the territories administered by Rome continued to speak languages derived from Latin after the fall of the empire), and although there are similarities between the ways in which Latin and English developed ( $\mathrm{I}$ am referring to the processes of 'indigenization'), the role of English as 'lingua franca' in the globalized world is mainly due to its success as the language of the British Empire (Mufwene, 2010, pp. 36-43, 50). The way in which Latin had spread within the Roman Empire closely resembles the situations of the Ancien Régime, and the way in which English has spread in Great Britain: the language still remains a social marker, since it reflects the social background, but the language right is in principle 'personal' (Dell'Aquila and Iannàccaro, 2004, pp. 19, 32): ideological and economic reasons are absent;

2. politico-ideological: in the contemporary world, the homogenizing force of linguistic imperialism meets the homogenizing forces of the traditional European language policies, whose ideology has consisted in the eradication of the local languages in favor of the national languages by resorting to the instrumental use of school and media that (together with the army) are the so-called 'instruments of deferred execution' (Bernini, 2014, pp. 165-170). Therefore, on the one hand, the language still plays a key role in legitimizing the state power, on the other one, English is not so much an ethnic marker but rather a social marker; 
3. economic: the power of the language is strictly bound to economic processes (as in the emblematic case of McDonaldization and CocaColonization) belonging to an economic situation very different from the ancient one: the following scheme (Figure 1), perfectly suitable to contemporary world in order to show the inseparable bond between language and economy, cannot be referred to the Roman Empire. Nowadays, the knowledge of English

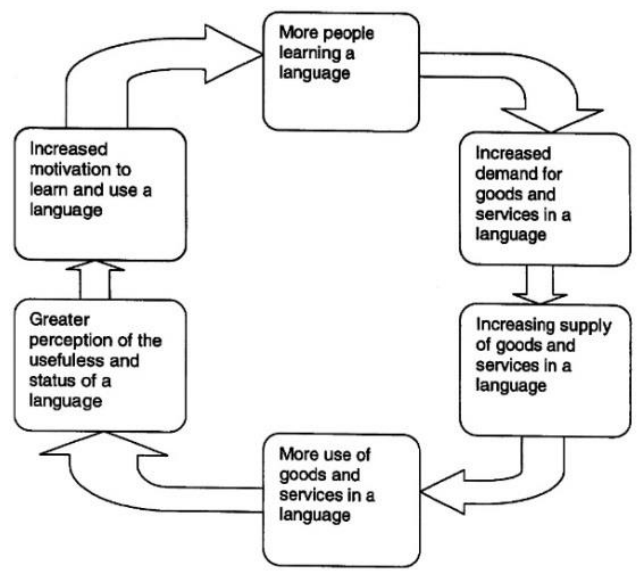

Fig. $1^{28}$. The Strubell's 'Catherine wheel' model yields many benefits, far more than Latin in the ancient world.

\section{Conclusion}

The ancients perceived imperialism and the imperialistic propaganda, but there is no evidence that there was a true linguistic imperialism, also because of the absence of a globalized context and of a state model resembling the modern nation-states: therefore, no language policy existed (at most one can speak of 'language supporting'). When referred to antiquity, the expressions 'globalization' and 'language policy' should be interpreted lato sensu, to indicate phenomena that, despite some similarities, are radically different: Roman imperialism does not mean linguistic imperialism. As for the linguistic viewpoint, the fundamental difference is that language is now a real instrument of power, a feature inherited by nation states, and nowadays mainly inspired by economic-political reasons.

${ }^{28}$ The Strubell's 'Catherine wheel' model, taken from Baker (2008, p. 438). 
The comparison between the past and the present goes beyond merely historical issues, thus casting light on the discussions about multilingualism. In particular, the analysis of the metalinguistic role played by the language in the Roman Empire demonstrates that the current bond between the language and the supra-local structures of power is not a permanent feature in history, and discredits the ideology according to which the hegemony of one powerful language is unavoidable.

\section{References}

Adams, J. N. (2003). Bilingualism and the Latin Language. Cambridge: Cambridge University Press.

Alonso-Núñez, J. M. (2004). Globalizzazione ed imperialismo romano. Patavium, 12(23), 3-12.

Alston, R. (2012). Augustan Imperialism. In D. Hoyos (Ed.), A Companion to Roman Imperialism (pp. 197-211), Brill: Leiden.

Anson, E. M. (2009). Greek Ethnicity and the Greek Language. Glotta, 85, 5-30.

Arcangeli, M. (2005). Lingua e società nell'era globale. Roma: Meltemi.

Baker, C. (2008). Foundations of bilingual education and bilingualism. Bristol: Multilingual Matters.

Barotchi, M. (2001). Lingua Franca. In R. Mesthrie (Ed.), Concise Encyclopedia of Sociolinguistics (pp. 503-504). Amsterdam: Elsevier.

Bernini, A. (2014). Languages as Intangible Cultural Heritage: about an 'Ecolinguistic Capital'. Darnioji Daugiakalbystè/Sustainable Multilingualism, 5, 164-186. DOI: http://dx.doi.org/10.7220/2335-2027.5.6.

Bombi, R., \& Graffi, G. (Eds.) (1998). Ethnos e comunità linguistica: un confronto metodologico interdisciplinare: atti del Convegno internazionale, Udine, 57 dicembre 1996. Udine: Forum.

Christes, J. (2001). Schule. In H. Cancik \& H. Schneider (Eds.), Der neue Pauly. Enzyklopädie der Antike (Vol. 11, pp. 263-268). Stuttgart - Weimar: Metzler.

Clackson, J. (Ed.) (2011). A Companion to the Latin Language. Malden, Mass: Wiley-Blackwell.

Coleman, K. M. (2006). Martial: Liber spectaculorum. Oxford: Oxford University Press. 
Crystal, D. (1997). English as a Global Language. Cambridge: Cambridge University Press.

Dell'Aquila, V., \& Iannàccaro, G. (2004). La pianificazione linguistica. Roma: Carocci.

Dubuisson, M. (1982). Y a-t-il une politique linguistique romaine? Ktèma, 7, 187210.

Eck, W. (2004). Lateinisch, Griechisch, Germanisch ...? Wie sprach Rom mit seinen Untertanen? In L. De Ligt, E. A. Hemelrijk \& H. W. Singor (Eds.), Roman Rule and Civic Life: Local and Regional Perspectives (pp. 3-19). Proceedings of the Fourth Workshop of the International Network Impact of Empire (Roman Empire, c. 200 BC-AD 476), Leiden, June 25-28, 2003 Amsterdam: Gieben.

Edwards, H. J. (1917). Caesar. The Gallic War. Cambridge, Mass.: Harvard University Press.

Edwell, P. M. (2012). Definitions of Roman Imperialism. In D. Hoyos (Ed.), A Companion to Roman Imperialism (pp. 39-52). Brill: Leiden.

Erskine, A., \& Mitchell, S. (2012). Imperialism in the Roman Empire (east). In R. S. Bagnall et al. (Eds.), The Encyclopedia of Ancient History (Vol. VI, pp. 3426-3431). Malden, MA: Wiley-Blackwell.

Farrell, J. (2001). Latin Language and Latin Culture: From Ancient to Modern Times. Cambridge: Cambridge University Press.

Green, W. M. (1963). Saint Augustine. City of God against the Pagans. Books IVVII. London: Heinemann.

Greene, W. Ch. (1960). Saint Augustine. City of God against the Pagans. Books XVIII, Chapter XXXVI, Book XX. London: Heinemann.

Hitchner, R. B. (2008). Globalization Avant la Lettre: Globalization and the History of the Roman Empire. New Global Studies, 2(2).

Hoyos, D. (Ed.) (2012). A Companion to Roman Imperialism. Brill: Leiden.

Hutton, M., \& Peterson, W. (1970). Tacitus. Agricola. Germania. Dialogus (revised by R. M. Ogilvie, E. H. Warmington \& M. Winterbottom). Cambridge, Mass: Harvard University Press.

James, A. (2009). Theorising English and globalisation: semiodiversity and linguistic structure in Global English, World Englishes and Lingua Franca English. Apples - Journal of Applied Language Studies, 3(1), 79-92. 
Moggi, M. (1998). Lingua e identità culturale nel mondo antico. In Bombi and Graffi (Ed.), Ethnos e comunità linguistica: un confronto metodologico interdisciplinare: atti del Convegno internazionale (pp. 97-122) Udine, 57 dicembre 1996. Udine: Forum.

Mufwene, S. (2010). Globalization, Global English, and World English(es): Myths and Facts. In N. Coupland (Ed.), The handbook of language and globalization (pp. 31-55). Malden, Mass: Wiley-Blackwell.

Mullen, A. (2011). Latin and Other Languages: Societal and Individual Bilingualism.

In J. Clackson (Ed.), A Companion to the Latin Language (pp. 527-548). Malden, Mass: Wiley-Blackwell.

Mullen, A. (2013). Southern Gaul and the Mediterranean: Multilingualism and Multiple Identities. Cambridge: Cambridge University Press.

Naerebout, F. G. (2006-2007). Global Romans? Is globalisation a concept that is going to help us understand the Roman empire? Talanta, 38-39, 149-170.

Oniga, R. (1998). Ethnos e comunità linguistica: uno sguardo dal mondo antico. In Bombi and Graffi (Ed.), Ethnos e comunità linguistica: un confronto metodologico interdisciplinare: atti del Convegno internazionale (pp. 573580) Udine, 5-7 dicembre 1996. Udine: Forum.

Phillipson, R. (2008). Lingua franca or lingua frankensteinia? English in European integration and globalization. World Englishes, 27(2), 250-267.

Phillipson, R. (2012). Imperialism and colonialism. In B. Spolsky (Ed.), Cambridge handbook of language policy (pp. 203-225). Cambridge: Cambridge University Press.

Phillipson, R., \& Skutnabb-Kangas, T. $\left(2013^{2}\right)$. Linguistic Imperialism and Endangered Languages. In T. K. Bhatia \& W. C., Ritchie (Eds.), The Handbook of Bilingualism and Multilingualism (pp. 495-516). Oxford Malden, Mass: Wiley-Blackwell.

Pitts, M., \& Versluys, M. J. (Eds.) (2014). Globalisation and the Roman World. World History, Connectivity and Material Culture. Cambridge: Cambridge University Press.

Pupavac, V. (2012). Language Rights: From Free Speech to Linguistic Governance. Basingstoke: Palgrave Macmillan.

Richardson, J. (2011). The language of empire: Rome and the idea of empire from the third century $B C$ to the second century $A D$. Cambridge: Cambridge University Press. 
Rivet, A. L. F., \& Smith, C. (1979). The place-names of Roman Britain. London: Batsford.

Rochette, B. (1995). Grecs et Latins face aux langues étrangères: contribution à l'étude de la diversité linguistique dans l'antiquité classique. Revue belge de philologie et d'histoire, 73(1), 5-16.

Rochette, B. (2011). Language Policies in the Roman Republic and Empire. (J. Clackson, Trans.). In J. Clackson (Ed.), A Companion to the Latin Language (pp. 549-563). Malden, Mass: Wiley-Blackwell.

Rushton Fairclough, H. (1999²). Virgil. Eclogues. Georgics. Aeneid (Books 1-6) (revised by G. P. Goold). London: Heinemann.

Rushton Fairclough, H. $\left(2001^{2}\right)$. Virgil. Aeneid (Books 7-12). Appendix Vergiliana (revised by G. P. Goold). London: Heinemann.

Schneider, E. W. (2011). Colonization, Globalization, and the Sociolinguistics. In R. Mesthrie (Ed.), Cambridge Handbook of Sociolinguistics (pp. 335-353). Cambridge: Cambridge University Press.

Sommer, M. (2013). Glocalising an Empire: Rome in the 3rd Century AD. In F. De Angelis (Ed.), Regionalism and Globalism in Antiquity (pp. 341-352). Leuven - Paris - Walpole, MA: Peeters.

Torallas Tovar, S. (2010). Linguistic Identity in Graeco-Roman Egypt. In A. Papaconstantinou (Ed.), The multilingual experience in Egypt, from the Ptolemies to the Abbasids (pp. 17-43). Farnham/Burlington, VT: Ashgate.

Vandorpe, K. (2012). Identity. In Ch. Riggs (Ed.), The Oxford Handbook of Roman Egypt (pp. 260-276). Oxford: Oxford University Press.

Witcher, R. (2000). Globalisation and Roman imperialism: perspectives on identities in Roman Italy. In E. Herring \& K. Lomas (Eds.), The Emergence of State Identities in Italy in the First Millennium BC (pp. 213-225). London: Accordia Research Institute, University of London. 
Andrea Bernini

Heidelbergo universitetas, Vokietija; andrea.bernini@zaw.uni-heidelberg.de

\title{
ANGLY KALBOS ŠIUOLAIKINIAME PASAULYJE IR LOTYNY KALBOS ROMOS IMPERIJOJE PALYGINIMAS: AR LINGVISTINIS IMPERIALIZMAS NAUJAS REIŠKINYS?
}

\begin{abstract}
Santrauka. Kai kurie mokslininkai, remdamiesi prielaida, kad tarp Romos imperijos ir šiuolaikinio globalizuoto pasaulio egzistuoja didelis panašumas, teigia, kad Romos imperijos lotynu kalbos bei šiandienio pasaulio anglu kalbos kaip supralokaliu kalbu vaidmenys yra labai panašūs. Vis dèlto šiu dvieju istoriniu reiškiniu apžvalga atskleidžia reikšmingus skirtumus. Pirma, lotynu kalba buvo supralokali kalba par excellence tik vakarinejje imperijos dalyje, kadangi rytinèje ši vaidmeni daugiausia atliko graiku kalba. Be to, nors Romos imperijos gyvavimo laikais lotynu kalba buvo administravimo kalba, apskritai ji neturejjo ypatingos itakos, nes tuomet nebuvo tradiciniu šiuolaikinès Europos kalbu sklaidos priemoniu nacionalinės kalbos koncepcija buvo nežinoma, nebuvo privalomo švietimo bei neegzistavo nieko panašaus i masines informavimo priemones. Žvelgiant i šiuolaikinę globalizuota visuomenę, galima pastebèti, kad kalba - esminis instituciju iteisinimo ir specifiniu ekonominiu jègu bei kultūru, susijusiu su tomis jègomis, palaikymo elementas. Šiuolaikinis anglu kalbos lingvistinis imperializmas ypatingai susijęs su tomis ekonominèmis jègomis, kurios susijungia ir pasinaudoja politinèmis, karinemmis, švietimo struktūromis ir masinès informacijos priemonemis (ta akivaizdžiai parodo McDonaldizacijos ir Coca-Colanizacijos procesai). Straipsnyje pateikiamas praeities ir dabarties salygu palyginimas neapsiriboja tik pačiomis situacijomis, bet kartu siekiama labiau paryškinti atitinkamus skirtumus - šiuo atveju atsigręžimas i praeiti leidžia kitu rakursu pažvelgti i šiuolaikines daugiakalbystès problemas.
\end{abstract}

Pagrindinès sąvokos: Senovès lotynu kalba, anglu kalba, lingvistinis imperializmas, Romos imperija, globalizacija, kalbu politika. 